University of Nebraska - Lincoln

DigitalCommons@University of Nebraska - Lincoln

Textile Society of America Symposium

Proceedings

Textile Society of America

2018

\title{
Along a Continuum: Spirally-woven Beadwork of the Tlingit, Wasco, and Pit River Peoples
}

Alice Scherer

Society of Bead Researchers, AS-beadweaver@outlook.com

Follow this and additional works at: https://digitalcommons.unl.edu/tsaconf

Part of the Art and Materials Conservation Commons, Art Practice Commons, Fashion Design Commons, Fiber, Textile, and Weaving Arts Commons, Fine Arts Commons, and the Museum Studies Commons

Scherer, Alice, "Along a Continuum: Spirally-woven Beadwork of the Tlingit, Wasco, and Pit River Peoples" (2018). Textile Society of America Symposium Proceedings. 1107.

https://digitalcommons.unl.edu/tsaconf/1107

This Article is brought to you for free and open access by the Textile Society of America at DigitalCommons@University of Nebraska - Lincoln. It has been accepted for inclusion in Textile Society of America Symposium Proceedings by an authorized administrator of DigitalCommons@University of Nebraska - Lincoln. 


\section{Along a Continuum: Spirally-woven Beadwork of the Tlingit, Wasco, and Pit River Peoples}

Paper presented at the annual conference of the Textile Society of America, Vancouver, BC, September 2018

\section{Alice Scherer AS-beadweaver@outlook.com}

In the late $18^{\text {th }}$ - and $19^{\text {th }}$-centuries European and American explorers and traders introduced small glass beads to the indigenous populations of the Pacific Northwest, bringing new elements of sparkle, regularity, and color to their decorative arts. The glass beads also inspired new techniques and fresh expressions, among them the weaving of beads into flat and tubular shapes.

Throughout the Pacific Northwest there have been examples of beads made of shell, seed, and stone whose origins predate contact with Europeans or Americans. Most such beads were strung and then worn around the neck, from the ears or nasal septum, or as small fringes attached to clothing. However, to date, native-made beads have not surfaced in my study area ${ }^{1}$ as having been woven into textile-like forms. (One possible exception seems to be netted headdresses, some of which were Columbia River women's puberty and/or wedding veils ${ }^{2}$ worked in dentalium and hide strips, while others in a similar style in Alaska served as aristocratic ceremonial regalia. ${ }^{3}$ In California, pieces of abalone shell were netted together to make a dance cap $^{4}$ that both glittered in the sun and would have made a lovely tinkling in movement.)

This paper focuses on some of the techniques devised by indigenous peoples to incorporate glass beads into their woven products, many of which techniques appear to have derived from earlier fiber traditions, most especially basketry and Plateau root storage bags. Both flat and tubular forms of this loose-warp work were created; in this paper I'll focus on those spirally-woven techniques that resulted in completed pouch or vessel forms not requiring a join to reach completion.

While many tribes in the greater Pacific Northwest made spirally-woven beadwork, here I'll look at the work of three specific tribes and their near neighbors. Beadwoven pieces were created in the Alaska panhandle among the Tlingit, along the Columbia River by the Wasco/Cascades, and in northeastern California along the Pit River and its tributaries, among the Achomawi and Atsugewi. Actual beadweaving by these three groups probably began on the lower- to midColumbia River in the 1840s, ${ }^{5}$ among the Wasco, Wishxam and Cascades, those easternmost of

1. Defined as ranging from the panhandle of Alaska to northern California, from the Pacific coast to approximately 150 miles inland.

2. Warren, Columbia Gorge Story, 62; photo portrait of Columbia River Native bride. https://commons.wikimedia.org/wiki/File:Edward_S._Curtis,_Wishham_bride,_Oregon,_1910.jpg

3. Henrikson, Steve, pers. comm.

4. Dance cap, Achumawi, c 1875, \#21378, National Museum of Natural History, Smithsonian Institution, Washington, D.C.

5. As evidenced by a loose-warp beadwoven panel bag (\#A5697.47-69) in the collection of the Natural History Museum of Los Angeles, clearly woven by Columbia River Native people per the motifs of sturgeon, (continued) 
the Chinookan peoples. From there it may have spread north to the Yakima and Klickitat and, with the Klickitat and other Plateau tribes, may have been carried west over the Cascades to the Puget Sound ${ }^{6}$ and also south to the Oregon and California/Nevada borders.

Woven beadwork as created by the Tlingit in the last quarter of the $19^{\text {th }}$ century may first have been introduced by more easterly Athapaskan tribes who were themselves exposed to tabbed and panel bags carried by Iroquois/Cree fur traders, and later, Cree and Métis settlers in western Canada. $^{7}$

What is Bead Weaving and How is it Formed?

As my general focus is on a form of beadwork often thought to be loomwork, and frequently described as such in museum records and various publications, this section will help the reader differentiate between loomed and loose-warp woven beadwork.

In loomwoven or secured-warp beadwork, the warp threads were held at either end on a loom or frame and kept taut during working. Generally all warps were added to the loom or frame at the same time. The finished form was usually a square or a rectangle, the latter sometimes quite a bit longer than it was wide (as in a belt or headband).

In loose-warp beadweaving, however, the act of working was much more freeform and largely performed in ways common to how baskets and root bags were woven. The work most often began at what is considered the bottom of the piece and a number of warps were connected to an initial section of weft, often at the warp centers, and the work of weaving began (Figure 1). The exact method varied by tribal area and piece, some examples of which I'll discuss below. While many examples of loose-warp beadwork were worked flat, others were worked "in the round", spiraling up and around to create pouch-like forms. In some cases this spiraling beadwork served instead to clothe a pre-existing form, most often a bottle or fiber basket.

To determine the method of manufacture of an historic piece, it helps to know how to differentiate between the two weaving methods when examining woven work. In loomed beadweaving, as the weft passes over an outer warp to commence the next row, a slant of weft on one outer warp and a wraparound "dot" of weft thread around the opposite outer warp always indicate loomed, or secured warp, beadweaving (Figure 2). Additionally, an " $\mathrm{X}$ " of weft threads crossing over both outer edges may sometimes indicate two-needle loomed beadweaving. However, the same " $X$ " would be seen with loose-warp beadweaving in which the double wefts are twined to allow the wefts to secure a finished row to an outside warp and make ready to

5. (continued) condors, deer and dogs. Collected in very early 1850 by Dr. William F. Edgar, assistant surgeon of the Mounted Riflemen, U.S. Military Expedition, 1849.

6. Harmon, Indians in the Making, 37, 85, 138; Williams, Bridge of the Gods, 74.

7. Duncan, So Many Bags, 57-59. 
commence the succeeding row. You would then need to search for other indications in the beadwork itself to determine whether you are observing fixed- or loose warp-beadweaving. Such signs could include warp threads in the body of the work that exchange places or warps that are drawn tightly down around a narrower bead or around a single bead above or below doubled beads. A clear indication of a paired weft twined around a warp, say if a bead has broken out and the wefts can be seen, would also indicate likely loose-warp beadweaving. These twined wefts in the body of the work could indicate that the piece itself was twined, though more likely it simply means the wefts naturally twisted and turned in the course of working the beads. (In order to be certain enough to label a piece as twined rather than simply loose-warp woven, one would need to see a number of broken beads in a row, all displaying twined wefts in the gap where the beads had been.)
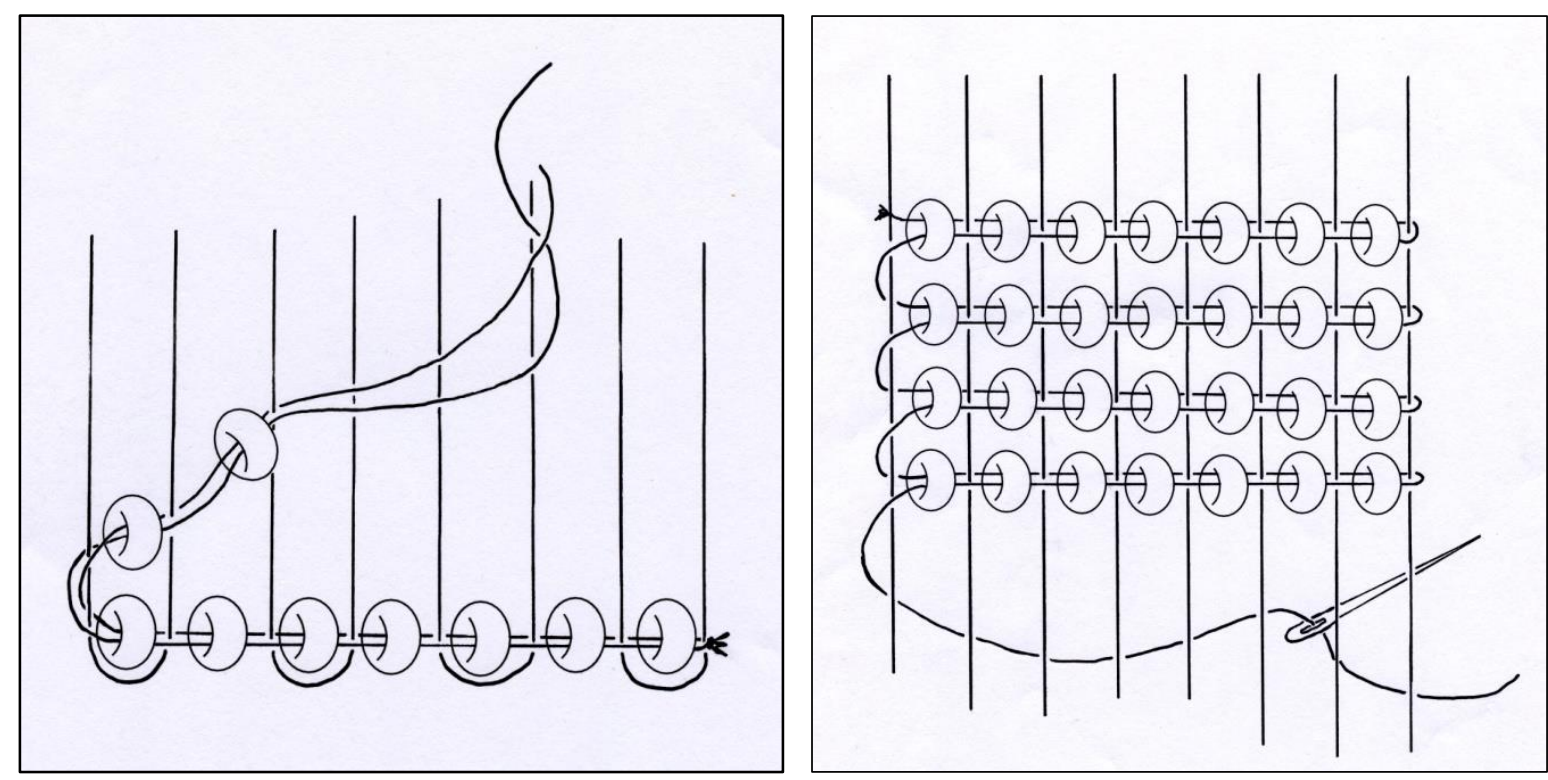

Figure 1: Loose-warp beadweaving. Figure 2: Loomed beadweaving. Illustrations by the author.

Beadweaving by the Tlingit Natives

In the northern end of the Pacific Northwest, the earliest regular non-Native contact was with Russians and Spaniards in the second half of the $18^{\text {th }}$ century, neither of whom would likely have had beadwoven material with them. Trade beads from that period seem largely to have been used for ornament, both of people and objects, although in general the Tlingit people at that time valued trade beads much less than did their brethren to the north and south, preferring iron instead. ${ }^{8}$ Exposure to beaded objects increased by the end of the first half of the $19^{\text {th }}$ century when the Hudson's Bay Company and Iroquois/Cree trappers moved into the area. ${ }^{9}$ As further

8. Emmons, Tlingit Indians, 184. "It is apparent that they [the Kaigani] have a great liking for articles made of iron and of copper, if they be not small. For the beads they did not show a great liking."

9. Duncan, So Many Bags, 57. 
beaded pieces filtered in from the Tlingit's Athapaskan neighbors to the east, they provided the likely source of inspiration for the Tlingit octopus ${ }^{10}$ and panel bags.

The overwhelming majority of beaded work made by the Tlingit were of beads embroidered on cloth in the form of bags, vests, and dance collars, some of which appear to descend directly from Native armor. ${ }^{11}$ A small percentage of Tlingit and Haida bags resemble Cree flat-woven panel bags with the Tlingit/Haida panels being noticeably shorter than Cree panels. ${ }^{12}$ The woven Tlingit beadwork with the clearest connection to pre-contact traditions is a number of hair ornaments held in museum collections; earlier examples were composed of "four or five parallel rows of dentalium", and "fringed with spun goat wool and beads at the bottom". ${ }^{13}$

In my observation, woven beadworks from this area tend to display geometric motifs. Although most pieces are worked with commercial thread, some early pieces, such as the one in Figure 3, include the use of Native-made fibers or sinew.

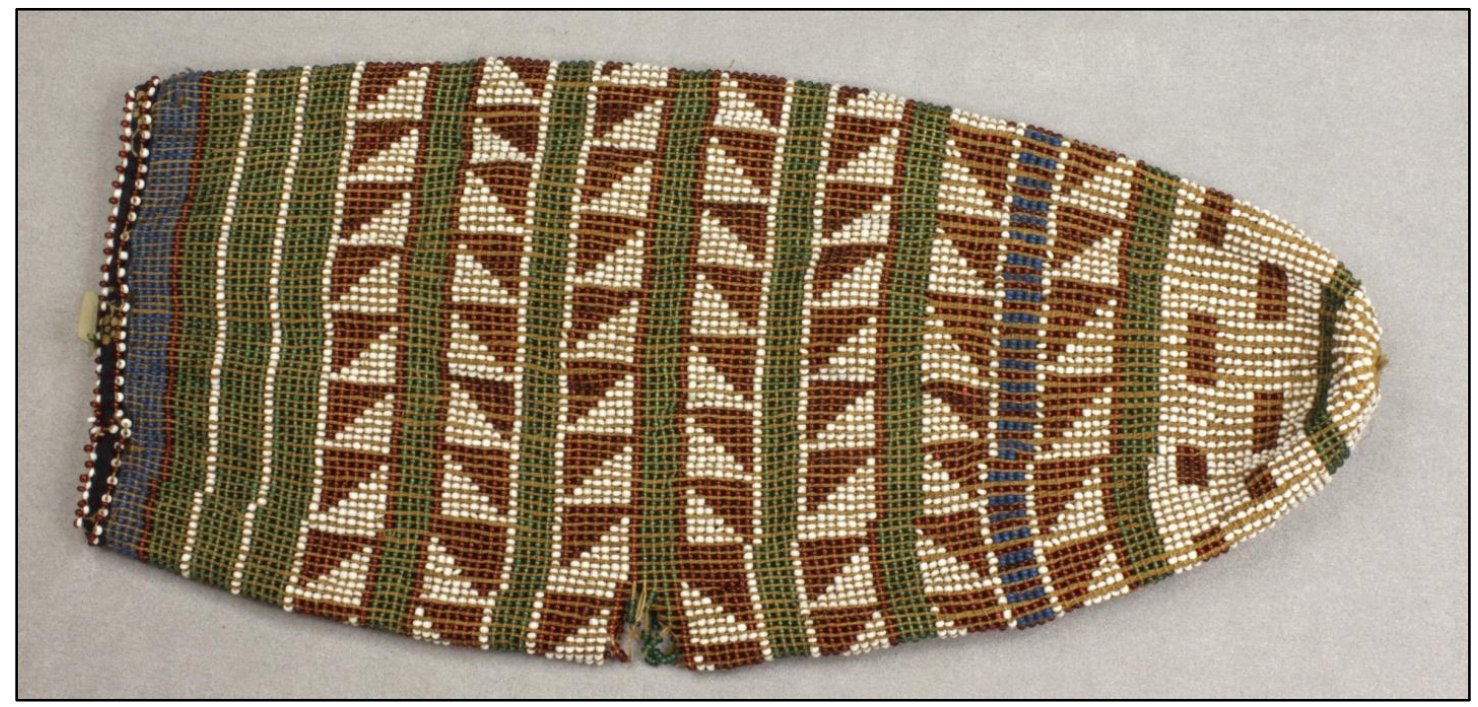

Figure 3: \#024450.000, J.E. Linde Collection, $27 \mathrm{~cm} \times 1 \mathrm{~cm} \times 12.5 \mathrm{~cm}$. National Museum of the American Indian, Smithsonian Institution. Photograph by the author.

In terms of spirally-beadwoven works originating in the Alaska panhandle, I'll review a pouch in the J.E. Linde collection at the National Museum of the American Indian in Washington, D.C. Its

\footnotetext{
10. An octopus bag is a large cloth bag with a number of pendular tabs suspended at bottom, also known as a "tabbed bag". That these are often in four pairs, resulting in eight "legs", has caused them to be referred to as octopus bags. While it's generally been assumed that this is some antique dealer's romantic term, Megan Smetzer posits otherwise in Tlingit Dance Collars, noting Alex Rasmussen's conveying to Frederic H. Douglas, director of the Denver Art Museum, that "One of my Indian friends tells me that the Tlingit name for the ceremonial pouch is translated 'devil fish finger pouch' and the name refers to the four double pendant parts which suggest the 8 tentacles of the octopus" (March 10, 1938 letter).
}

11. Smetzer, Tlingit Dance Collars, 64-73.

12. Author's personal observation from a number of pieces studied.

13. Emmons, Tlingit Indians, 240. 
original purpose may have been to serve as a "wallet", a woven and flattened bag meant to be folded when in use or perhaps worn suspended over a belt. In Figure 3, a section of broken threads at the center of the bag supports the impression that the piece may have been repeatedly folded over and perhaps stuffed under a belt or into a pocket. This spirally-woven beaded bag was begun when a number of likely cedar warps were grouped together and bound with soft, loosely-spun cordage (Figure 4); what may be commercial thread then acted as the weft as the pouch was worked. As the circular bottom of the bag widened, grouped warp threads were unbundled into first double, then single, warps to allow for more working strands, much as is true in the construction of many baskets throughout the Pacific Northwest (Figure 5).
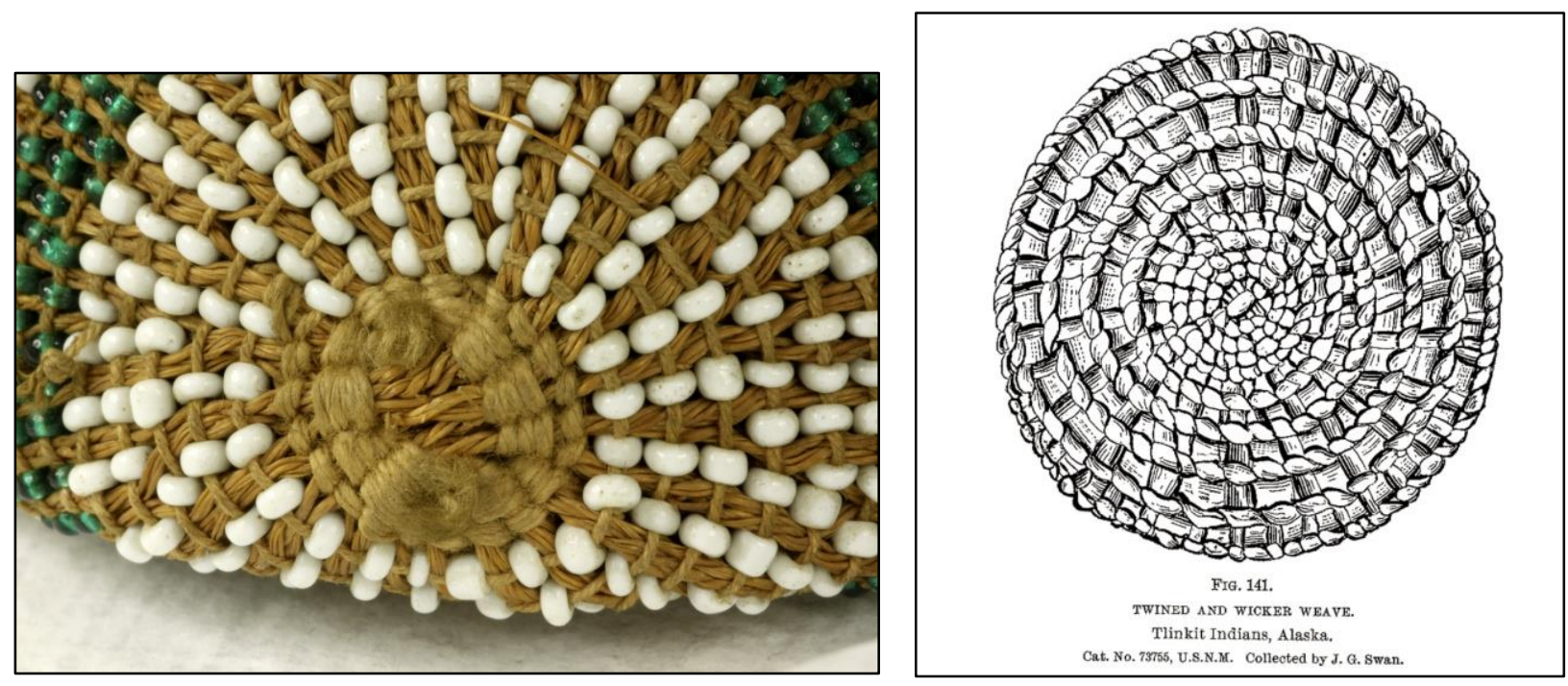

Figure 4: View of the weaving start at the bottom of the bag in Figure 3. Photograph by the author. Figure 5: Drawing of a Tlingit cedar basket start, from Aboriginal Indian Basketry, by Otis Tufton Mason, p. 411.

Over time, these loosewarp-woven forms were no longer made as fashion, society in general, and Tlingit society in particular changed with the times. In the case of far Pacific Northwest coastal peoples, over the last half century a more particularized form of traditional material has became increasingly popular, with revived forms of regalia including button blankets and beaded octopus bags taking precedence over the potential revival of more homely and shorter-lived forms of early beadwork, including loose-warp beadwoven pouches, baskets, and bottle covers.

Beadweaving by the Wasco Natives

Heading south from Alaska, we arrive at the lower- to mid-Columbia River, home of the easternmost Chinookan peoples: the Wasco, Wishxam, and Cascades. In speaking of the Natives of the Columbia River and their beadwork, we acknowledge their extensive and frequent contact with the folks at the Hudson's Bay Company fur trading post at Fort Vancouver. Passing through the Fort was a considerable profusion of European, American and Asian goods that both enhanced and altered the lives of the local peoples. In exchange for their furs, fish, camas roots, and woven mats, Native people traded at the Fort for beads, guns, cooking pots, metal bracelets, 
and other goods. ${ }^{14}$ Additionally, the local people would have been quite familiar with the sight of the voyageurs and other fur traders with beaded items on their persons, ${ }^{15}$ as well as the beaded leggings of the wife and daughter of Dr. John McLoughlin, the Fort's chief factor, and other officers' wives. ${ }^{16}$

While the names of most Native women who produced beadwork are unknown to us, we know of at least one family along the Columbia River who produced woven beadwork in this area. Mumshumsie and Taswatha (later "Ellen") were the extremely prolific wife and daughter of Welawa, or Chief Chenewuth, of the Cascades band of Chinook. ${ }^{17}$ (They have variously also been described as Wasco or Klickitat.) In public accounts of their history, this beading family takes its name from Ellen's second husband, Amos Underwood, a settler from Ohio. During the second half of the $19^{\text {th }}$ century, Underwood's land claim was close to his wife's ancestral homeland, ensuring continued family relations. ${ }^{18}$

Fiber work produced throughout the Plateau, both in root bags and beadwork, tended to have dissimilar designs front and back (if designs were included on both sides), with geometric motifs on one side and more pictorial, often floral, designs on the other. ${ }^{19}$ Those beaded works generally considered to be among the earliest were often woven on sinew and/or thigh-spun Indian hemp (Apocynum cannabinum), though over time commercial thread, usually cotton, supplanted these.

I'll now investigate a small sample of the work done in this area; both pieces shown are thought likely to be the work of the Underwoods. The first is a small flat, squarish bag, the work progressing spirally, most likely from the bottom up (Figure 6). The number of beads between warps is uneven: sometimes two or even three, a diagnostic I've found to generally be indicative of earlier work. The simple, two-color loops at bottom may be the prototype for a style element common in later Underwood work (below). Figure 7 shows a far more evenly-worked piece in which the Underwood style has reached its apotheosis. The designs are well thought out and organized in bands separated by horizontal lines. The simple loops as seen at the bottom of the piece in Figure 6 have finalized in Figure 7 to a small loop at top with a larger loop suspended below, also in a two-color format. The tops of bags such as in Figure 7 were finely finished with buckskin or ribbon edging, an embroidered edge trim of looped beads, and buckskin handles.

14. The range of goods traded between parties was considerable. This listing comprises only a small portion of the recorded trade as noted in innumerable publications.

15. Schlick and Duncan, Wasco-Style Woven Beadwork, 36-45.

16. Wilkes, Narrative of the United States Exploring Expedition, 370.

17. Warren, Columbia Gorge Story, 1; Schlick and Duncan, Wasco-Style Woven Beadwork, 37.

18. Warren, Columbia Gorge Story, 86.

19. Personal observation over many dozens of pieces studied. 

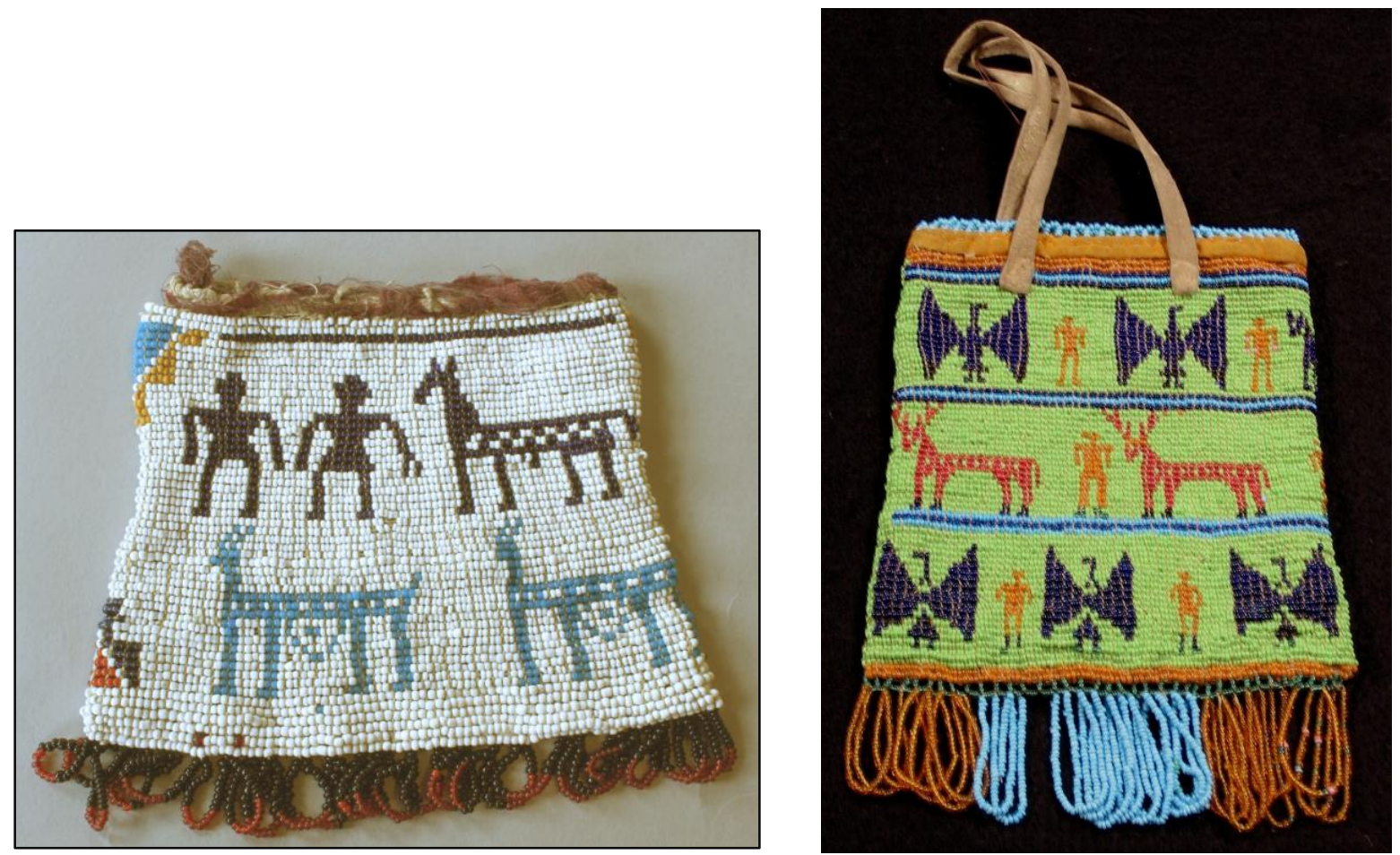

Figure 6: Flat spirally-woven bag, c. 1880-1890, $11.43 \mathrm{~cm}$ x c $12.7 \mathrm{~cm}$. Courtesy Pamplin International Collection of Art \& History, with special thanks to collections manager Chet Orloff.

Figure 7: Courtesy Lee and Lois Miner, c. 1890-1915, $19.685 \mathrm{~cm} x 13.335 \mathrm{~cm}$. Photographs by the author.

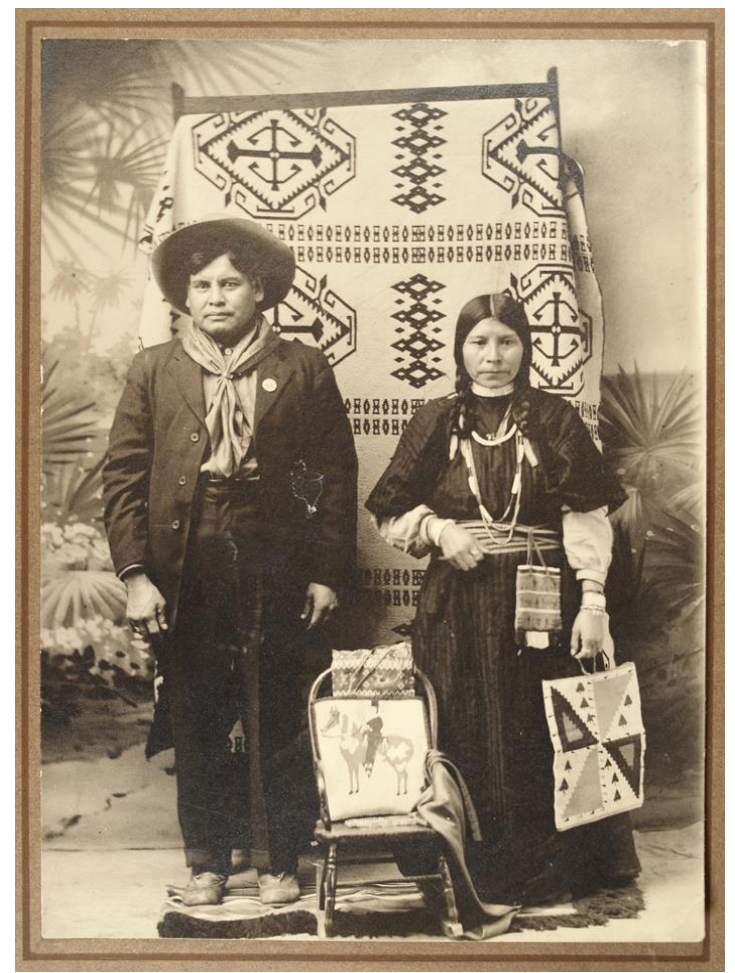

Figure 8: Photograph taken after 1909 by Jonas Loranson, a Toppenish, Washington, photographer. Courtesy Lee and Lois Miner, with special thanks to Richard Storch. 
A photograph taken by Jonas Loranson, a Toppenish, Washington, photographer in the early $20^{\text {th }}$ century, shows a bag very similar to the one in Figure 7 suspended from the woman's sash belt (Figure 8). The bags share similar characteristics, including three bands of figures, lighter beads in the central portion of the fringe, and a likely buckskin strap through which the sash belt is threaded.

In addition to these large bags, smaller, more rectangular pouches were also created, perhaps to offer more quickly-made goods for sale or gifting. Of the Underwood body of work, these latter bags (not pictured here) are among the most commonly-found examples.

Photographs I've examined from the late-1800s through mid-1900s of Indian School attendees from around the country illustrated the growing prevalence of bead looms and frames for the making of Native-woven beadwork. All traces of these spirally-woven bags and loose-warp woven bands and panels seem to have vanished from the photographic record along the Columbia River by about 1920 or so. In their place were more often found loomwoven bands: long, rectangular and quite even.

\section{Beadweaving by the Pit River Natives}

To conclude, we now head farther south to the home of the Pit River peoples, just south of the Oregon/California border and relatively near Nevada.

Given the comparative isolation of the region, beads took longer to arrive here in any great quantity than they did in other segments of my study area. The mountainous terrain was largely passed through only by fur traders and explorers ${ }^{20}$ until the gold rush began in 1849 and rapacious miners rapidly infiltrated the most distant California watersheds. ${ }^{21}$ Of the three areas described in my paper, the people-to-people interactions in northern California were among the most destructive to native peoples and their cultures and the recovery periods among the most difficult and prolonged.

As regards sources of inspiration, beadwork from the Columbia River area may occasionally have been seen as there was active trade between the Klickitats and other Plateau tribes and the Klamath/Modoc, ${ }^{22}$ by which trade beaded objects could have filtered south. Certainly the few tabbed Native-made pieces I've seen from northern California suggest at least a passing awareness of tabbed bags, if not an intimate familiarity.

20. Renfro, Shasta Indians of California, 91.

21. Faulk, Modoc, 27.

22. Neils, Klickitat Indians, 70. 

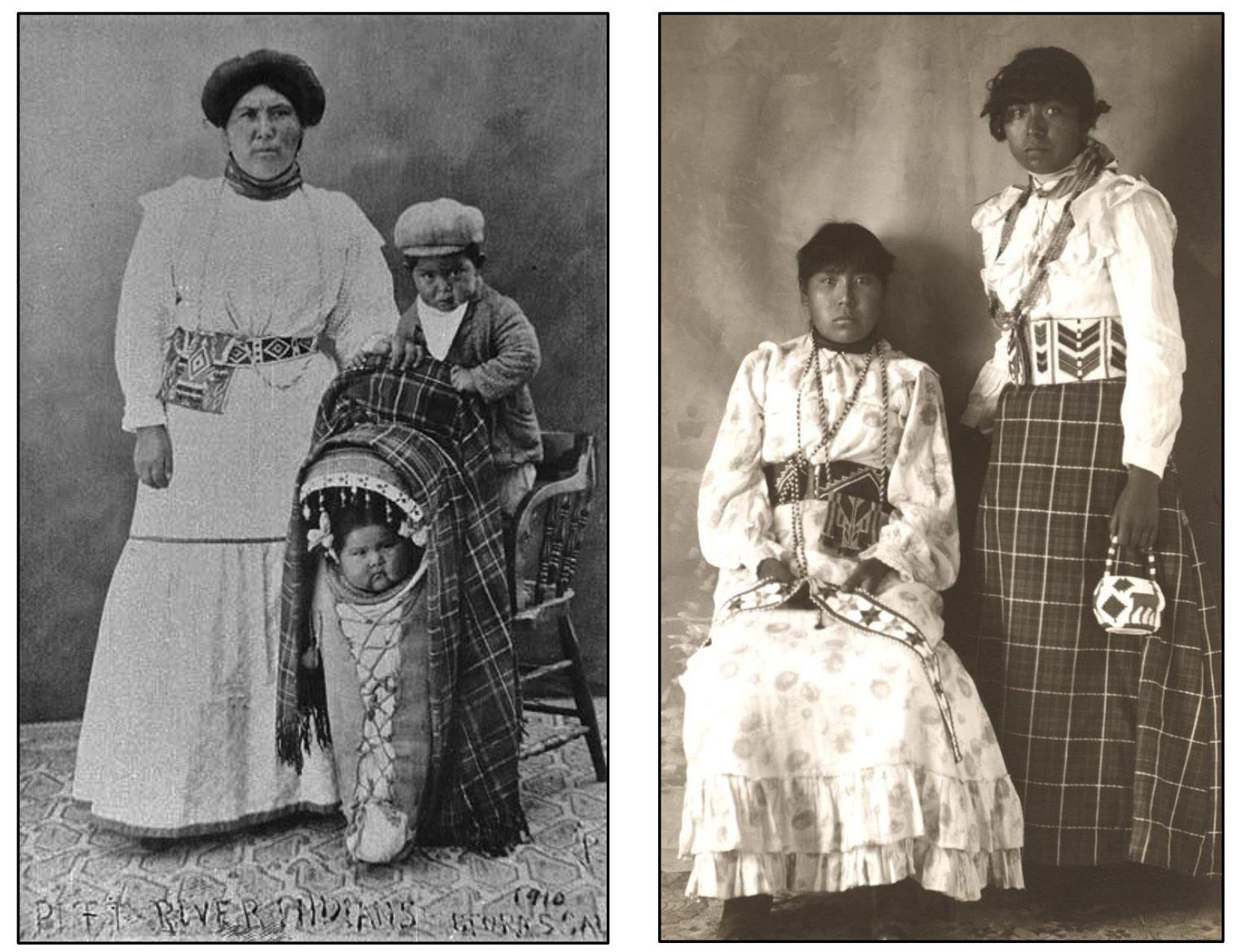

Figure 9: Pit River Native Gertrude Ryan, with her children Griffith Mike Ryan and Cecil Mike Ryan, c 1910. Courtesy of the Shasta Historical Society, 1950.196.1.

Figure 10: Courtesy of the Southern Oregon Historical Society, \#20942.

The form of Pit River beadwork discussed here will be the beaded purse, of which many hundreds, perhaps thousands, were created. From perhaps 1885 through the mid- $20^{\text {th }}$ century, along with other forms such as beaded bottles, chalices, and cups with handles, these bags were popular items for people to make in their homes for sale to white collectors. ${ }^{23}$ Native women, however, also proudly wore them as their own, as can be seen in Figure 9 and possibly 10. The most common shape was the square or rectangle with a flap from the extended back hanging over the front, but a significant number were also worked in a diamond shape. I've observed that the backs of the bags generally sport the same geometric design as the front and, at least for these bags, the threading material is universally commercial thread, nearly all of black warps and white or cream wefts. Note that I refer to "Pit River" bags, but at least some of these bags were likely also made by a number of different tribal people in this area, including possibly Klamath, Modoc, Paiute, and Wintun peoples. However, they are most closely associated with the Pit River people, the Achomawi and Atsegewi.

23. Odgers, Basketry and Beadwork of the Modocs, 19, 23. 

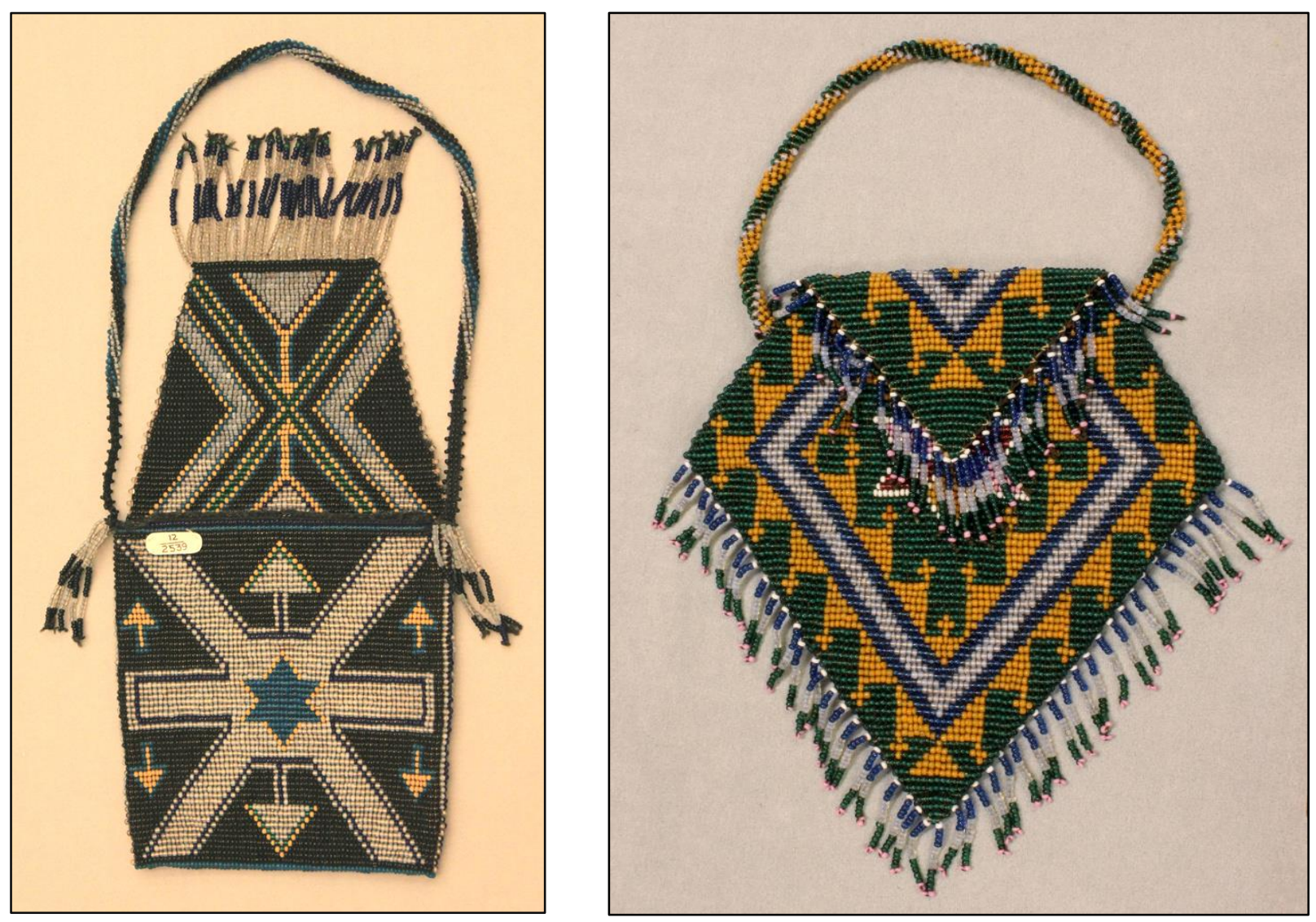

Figure 11: \#12/2539, $22 \mathrm{~cm} \times 12 \mathrm{~cm}$. Courtesy Museum of the American Indian, Smithsonian Institution. Figure 12: Private collection, $17.78 \mathrm{~cm} \times 15.621 \mathrm{~cm}$. Photographs by the author.

As with all Pit River bags, the work for these began at the bottom. A number of beads ${ }^{24}$ were threaded on a doubled weft, then warp threads were slid between the beads, through the gap between the wefts, with the center of the warp abutting the beads (Figure 13). One half of each warp thread constituted either a front or rear warp. At the end of the first and second rows, extra beads were added at the sides along with extra warps to allow for the development of depth in the bag. Once the first three rows were established, the work proceeded spirally to the top of the front, where the warps were then braided and trimmed. The beading continued as flat work on the remainder of the bag and shortly began to narrow on both sides, allowing for an angled flap. After the flap was completed, beads were often strung on the warps for fringe. The bag in Figure 11 had a handle that was woven in place from extra-long warps used in the side of the bag. The majority of bags, however, had handles that were woven separately and attached afterward. ${ }^{25}$ It is possible this change in procedure was made due to the fragility of the handle at the point of connection, with separately-made handles being more durable and more easily replaced.

24. The desired width at bag bottom determines the number of beads strung for the first row. 25. Personal observation across many dozens of pieces. 


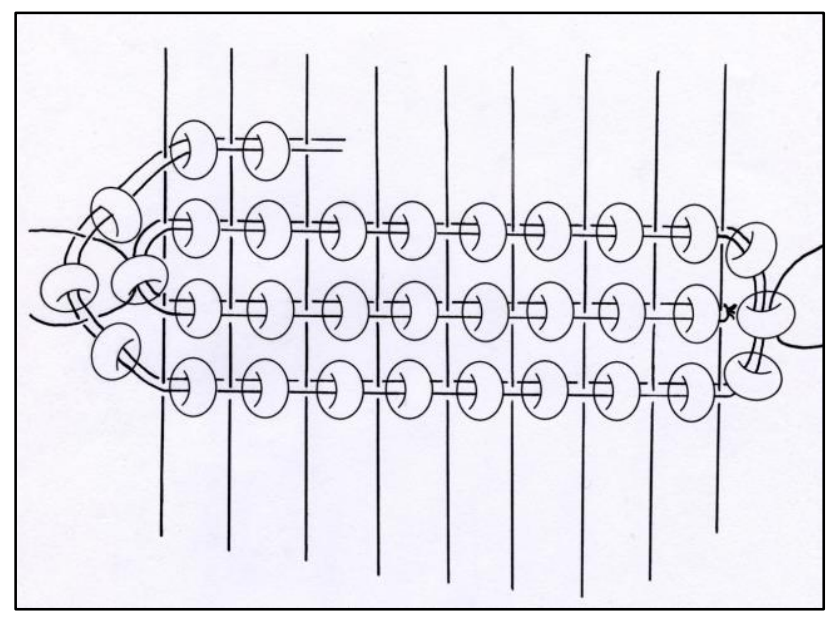

Figure 13. The central horizontal row is strung first and begins at far right. The added warps at the sides could be inserted either through the doubled wefts or through the beads as shown in my illustration. Although this diagram appears to show flat work, it is for the sake of clarity only. As the work progresses into the fourth through sixth rows, the beadworker uses thread tension to pull the work up into the intended tubular shape. Illustration by the author.

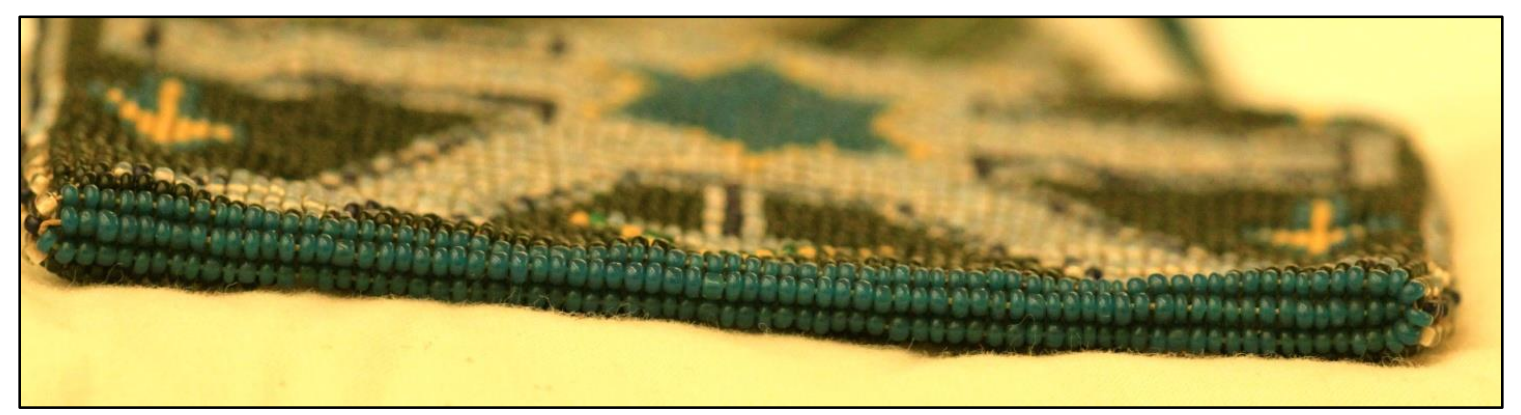

Figure 14: Looking more closely at the bottom of the bag in Figure 11, we see the bag start with the first three rows of blue beads which set the warps. Photograph by the author.
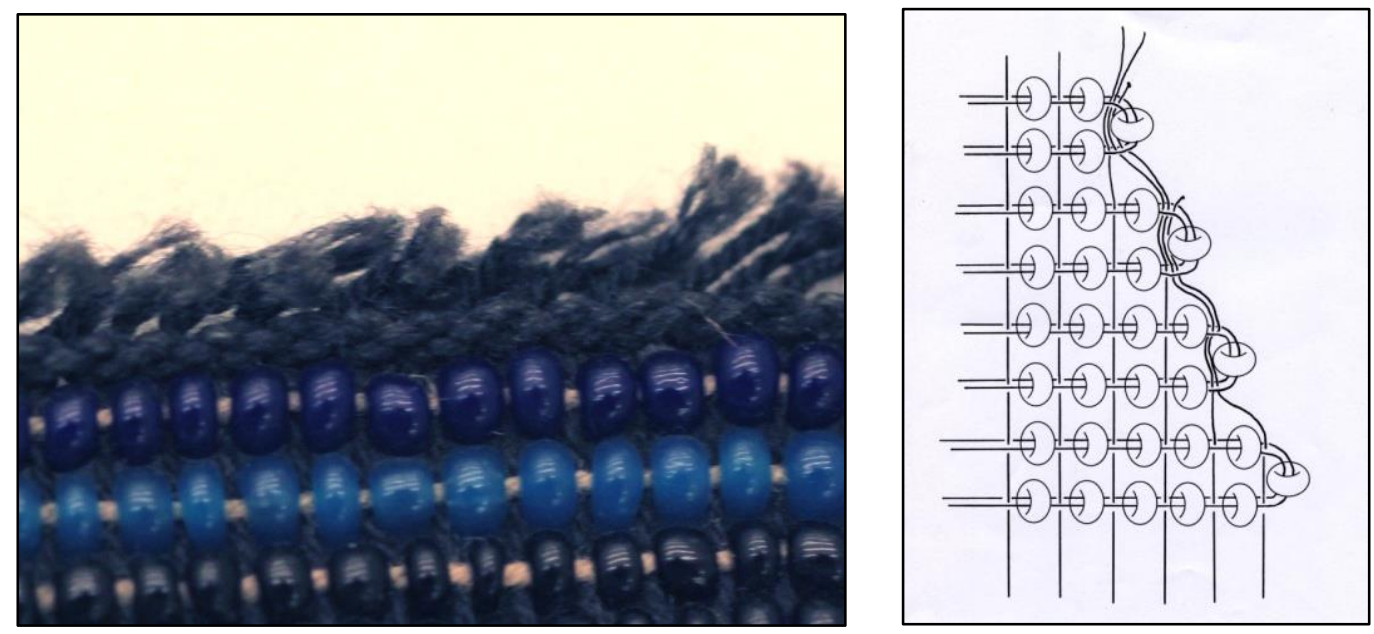

Figure 15. Looking at the front top of the bag in Figure 11, note the bag finish after the warps were braided and clipped. Photograph by the author.

Figure 16: The reduction of the warps on the sides of the flaps, illustration by the author, after Orchard. 
The diamond-shaped bags were woven in basically the same way as the square or rectangular bags. However, while the square or rectangular bags began with a first row spanning the width of the bag, the first row of diamond-shaped bags began with as few as one to three beads to anchor the start. The weaving rapidly broadened in both directions from there, with additional warps added per each row until the side apexes were reached. To complete the body of the bag, in succeeding rows superfluous warp threads were knotted off and clipped inside the bag as the remainder of the rows were woven in a narrowing format until the top of the front of the bag was reached. The finishing of the top front and the construction of the flap proceeded as in the previous description while however reducing the flap to a point.

Colors were more subdued in earlier examples of Pit River beadwork. Over time, the beads became brighter and the shapes and construction methods of both handles and bags grew more varied. Of the three tribal areas discussed in this paper, the creation of spirally-woven beadwork in northern California continued the longest, with some work continuing into the 1970s.

\section{Changes, Great and Small}

As white settlers poured into the Northwest in the 1800s, creating villages, towns and cities, and crowding out the original peoples who'd lived here for millennia, Native peoples were forced by circumstance to adapt to the changed economic environment. Native men worked in lumbering, fishing, and on ranches, ${ }^{26}$ Native women worked as domestics. ${ }^{27}$ Both harvested local food products which they sold or traded to white settlers, ${ }^{28}$ and women made craft products such as baskets, moccasins, gauntlets, and beadwork, and sold or traded those as well.

In looking at and examining hundreds of pieces, I've observed that in general embroidered beadworks throughout the greater Pacific Northwest vastly outnumbered woven ones, with the loose-warp woven works discussed in this paper comprising only a fraction even of that. This suggests that a much smaller percentage of the female population chose to do this more fiddly and time-consuming work than did those who chose to embroider beads onto cloth or who used a bead loom/frame to weave beads.

Regrettably, it's impossible to know who crafted the first loose-warp beadwork in any of these areas, though one might readily imagine that those well versed in basketry may have been the original and most skilled practitioners. Nevertheless, we are thankful that so many of their works and those of their successors have survived, being both available for study and allowing us to appreciate the beauty of the work and the creativity and skill of their makers. May these sleeping forms yet awaken and be renewed.

26. Harmon, Indians in the Making, 60, 170; Costello, The Siwash, 163; Sengstacken, Destination, West!, 133, 145.

27. Harmon, Indians in the Making, 60.

28. Ibid. 
Bibliography

Costello, J.A. The Siwash: Their Life, Legends and Tales. Seattle, WA: The Calvert Company, 1895.

Duncan, Kate C. "The Evolution of Two Algonquian Bag Forms," Out of the North: The Subarctic Collection of the Haffenreffer Museum of Anthropology Brown University. Bristol, RI: Haffenreffer Museum of Anthropology, Brown University, 1989, 86-95.

. "So Many Bags, So Little Known: Reconstructing the Patterns of Evolution and Distribution of Two Algonquian Bag Forms". Arctic Anthropology, Art and Material Culture of the North American Subarctic and Adjacent Regions, 28 no. 1, 1991: 56-66.

Historic Research Study: Beadwork at Fort Vancouver 1840-1860 with

Recommendations for Beaded Items to Replicate, unpublished report for Fort Vancouver, Vancouver, Washington, 2009.

Emmons, George Thornton. The Tlingit Indians, edited with additions by Frederica de Laguna. Seattle, WA and London: University of Washington Press and New York: American Museum of Natural History, 1991.

Faulk, Odie B. and Laura E. Faulk. The Modoc. Frank W. Porter III, General Editor, Indians of North America Series. New York: Chelsea House Publishers, 1988.

Harmon, Alexandra. Indians in the Making: Ethnic Relations and Indian Identities Around Puget Sound. Berkeley, CA: University of California Press, 2000.

Lessard, F. Dennis. “Great Lakes Indian 'Loom' Beadwork”, American Indian Art Magazine, Summer 1986: 54-61, 68-69.

Mason, Otis Tufton. Aboriginal Indian Basketry. Glorieta, NM: The Rio Grande Press, Inc.: 1972. Originally published in 1902 by the Smithsonian Institution, Washington, D.C.

Mercer, Bill. People of the River: Native Arts of the Oregon Territory. Portland, OR.: Portland Art Museum, in association with University of Washington Press, Seattle and London, 2005.

Neils, Selma. The Klickitat Indians. Portland, OR: Binford \& Mort, Publishing, 1985.

Odgers, Ann. "The Basketry and Beadwork of the Modocs, Achumawi, and Northern Paiutes", The Journal of the Modoc County Historical Society, Native American Issue, 1990 no. 12, 11-24.

Orchard, William C. Beads and Beadwork of the American Indians. New York: Museum of the American Indian, Heye Foundation, 1929, 1975.

Renfro, Elizabeth. The Shasta Indians of California and Their Neighbors. Happy Camp, CA: Naturegraph Publishers, Inc., 1992. 
Schlick, Mary Dodds. Columbia River Basketry: Gift of the Ancestors, Gift of the Earth. Seattle, WA.: University of Washington Press, 1994.

. Flat Talisman Bag and Round Treasure Bag. Mt. Hood, OR: Mary Schlick, 2001. and Kate C. Duncan. "Wasco-Style Woven Beadwork: Merging Artistic Traditions", American Indian Art Magazine, Summer 1991: 36-45.

Sengstacken, Agnes Ruth. Destination, West!: A Pioneer Woman on the Oregon Trail. Portland, OR: Binfords \& Mort, Publishers, 1942.

Smetzer, Megan A. Threads of Resistance: Unraveling the Meanings of $19^{\text {th }}$ Century Tlingit Beaded Regalia. Textile Society of America Conference, Northampton, Massachusetts, September 26, 2002. https://digitalcommons.unl.edu/tsaconf/416/ . "Tlingit Dance Collars and Octopus Bags: Embodying Power and Resistance", American Indian Art Magazine, Winter 2008: 64-73.

Warren, Esther. The Columbia Gorge Story. Newport, OR: Esther Warren, 1977.

Wilkes, Charles, U.S.N. Narrative of the United States Exploring Expedition. Vol. 4. Philadelphia: Lee and Blanchard, 1845; Upper Saddle River, NJ: Gregg Press, 1970.

Williams, Chuck. Bridge of the Gods, Mountains of Fire: A Return to the Columbia Gorge. Hood River, OR and Seattle, WA: Friends of the Earth and Elephant Mountain Arts, 1981. 